\title{
Review of the Data Bases for Making Decisions Regarding Trojan Steam Generator Replacement Options
}
A. B. Johnson, Jr.
E. R. Gilbert

March 1992

Prepared for

Bonneville Power Administration under a Related Services Agreement with the U.S. Department Energy Contract DE-AC06-76RLO 1830

Pacific Northwest Laboratory Operated for the U.S. Department of Energy by Battelle Memorial Institute 


\title{
DISCLAIMER
}

This report was prepared as an account of work sponsored by an agency of the United Siates Government. Neither the United States Government nor any agency thereof, nor Battelle Memorlal institute, nor any of their employees, makes any warranty, expressed ur implied, or assumes any legal liability or responsibility for the accuracy, completeness, or usefuiness of any information, apparatus, product, or process disclosed, or represents that its use would not infringe privately owned rights. Reference herein to any specific commercial product, process, or service by trade náme, trademark, manufacturer, or otherwise does not necessarily constitute or imply its endorsement, recommendation, or favoring by the United States Government or any agency thereof, or Battelle Memorial Institute. The views and opinions of authors expressed herein do not necessarily state or reflect those of the United States Government or any agency thereof.

\author{
PACIFIC NORTHWEST LABORATORY \\ operated by \\ BATTELLE MEMORIAL INSTITUTE \\ for the \\ UNITED STATES DEPARTMENT OF ENERGY \\ under Contract DE-AC06-76RLO 1830
}

Printed in the United States of America

Available to DOE and DOE contractors from the

Office of Scientific and Technical Information, P.O. Box 62, Oak Ridge, TN 37831; prices available from (615) 576-8401. FTS 626-8401.

Available to the public from the National Technical Information: Service, U.S. Department of Cemmerce, 5285 Port Roval Rd., Springfield, VA 22161. 
REVIEW OF THE DATA BASES FOR MAKING DECISIONS REGARDING TROJAN STEAM GENERATOR REPLACEMENT OPTIONS

A. B. Johnson, Jr.

E. R. Gilbert

March 1992

Prepared for Bonneville Power Administration under a Related Services Agreement with the U.S. Department of Energy under Contract DE-ACO6-76RLO 1830

Pacific Northwest Laboratory

Richland, Washington 99352 


\section{SUMMARY}

The central focus for this assessment has been to compare the corrosion behavior of two SG tube materials: Inconel 600 TT and Inconel 690 TT from a) SG operating experience, and b) laboratory data. The scope and results of the comparisons are summarized in this section. They provide the basis for projecting SG longevity.

\section{SCOPE AND RESULTS BASED ON REACTOR SERVICE}

Due to the complex nature of $S G$ design and operation, it is not valid to fully isolate material behavior as a variable. Rather, we present an integrated perspective that includes SG design, operation, and materials. Isolation of materials comparisons is addressed in the laboratory studies (Sections 4 and 6.2).

\section{A110y 600 TT}

The data base focuses on thermally-treated Inconel 600 in U.S. reactors fabricated by Westinghouse, to maintain relevance to the Seabrook Unit 2 units that are under consideration. The fact that $49 \mathrm{SGS}$ in U.S. reactors (about 80 worldwide) with a combined experience of 280 SG-years have operated for periods up to 11 years (through 1992), free of tube plugging due to corrosion (data through 1990) is substantial evidence that major advances have been made in controlling SG degradation. Higher integrity tube material is only one factor in the complex array of potential contributors that include improved water chemistry control, removal of copper sources, advancements in crevica design, and more corrosion-resistant tube support and tube sheet materials.

Based on reactor service experience we conclude that Alloy 600 TT is emerging as a satisfactory material for extended operation in SGs. There seems to have been little opportunity in recent service to evaluate how the material will behave in severe upset conditions, e.g., such as the brackish water ingress at Indian Point Unit 3. However, specific strengths and vulnerabilities are considered, based 0" laboratory results (Section 5). 


\section{A1loy 690 TT}

The reactor service data base for Alloy 690 TT was summarized in Table 2: 11 SGs in service for about 30 SG-years, with a maximum service time of about three years. While the service experience has been positive (no tubes plugged for any cause), the experience, by itself, provides an insufficient basis for major conclusions.

\section{LABORATORY RESULTS}

Testing of Alloy 690 TT for periods of up to four years in primary coolant chemistry and up to eight years with secondary system chemistry consistently shows more resistance to cracking than similar testing of Alloy 600 MA or 600 TT. No detectable degradation has been found in most tests or during the steam generator reactor service. Extrapolations with limited validity imply that the margin of performance improvement provided by Alloy 600 TT over Alloy 600 MA in SGs is at least twice the service longevity. The use of Alloy 690 TT over Alloy 600 TT should provide an unbounded improvement on the primary side, but perhaps only an additional improvement of a few years for the secondary side. However, it should be realized that the actual performance is affected by numerous factors and may not be realized unless the operating parameters of a steam generator are rigorously controlled within guideline operating ranges.

Limited extrapolations suggest that the Model $F$ heat exchangers with Alloy 600 TT tubes now at Seabrook 2 should provide 20 to 25 years service at the Trojan Plant, particularly if some deficiencies indicated in Section 6.1 are corrected. Similar heat exchangers now in service have provided over 10 years service with no tubes plugged because of cracking. New heat exchangers with Alloy 690 TT could provide at least an additional 30 to 35 years service at the Trojan Plant if secondary-side performance is amply represented by available laboratory tests. Based on compatibility with the primary coolant, the margin of improvement provided by the Alloy $690 \mathrm{TT}$ should be even greater. However, because of the complexity of the secondary system environment in localized regions, the margin of improvement over Alloy $600 \mathrm{TT}$ could be lower. 


\section{OPTIONS FOR TROJAN SG REPLACEMENT}

Selection of either a) the Seabrook SGs (with precautions indicated in point 11 of the conclusions) or b) a SG with Alloy 690 TT tubes seems substantially justified on materials grounds. Economic and political considerations can then enter strongly into the decision process. 


\section{NOMENCLATURE}

${ }^{\circ} \mathrm{C}$

degree centigrade

Alloy 600 Inconel 600

Alloy 690 Inconel 690

Alloy 800 Incoloy 800

AVT

all volatile treatment

BPA

Bonneville Power Administration

C

carbon

$\mathrm{Cr}$

chromium

Elong

elongation

$\mathrm{Fe}$ iron

Fret (LP) fretting by loose parts

Fret (Preh) fretting in preheater

Fret (AVB) fretting by antivibration bar

$\mathrm{g} / \mathrm{L} \quad$ grams per liter

h hours

ID inside diameter

IGA intergranular attack

Incone ${ }^{\oplus}$ Nickel-base alloy (see Appendix A, Table Al)

$K_{I_{S C}} \quad$ threshold stress intensity factor for stress corrosion cracking KWSCC Kraftwerk Union

m meters

MA mill annealed

min minimum

$\mathrm{MPa} \quad$ megapascal

$\mathrm{Ni}$ nickel

OD outside diameter

PNL

Pacific Northwest Laboratory

PWR pressurized water reactor

PWSCC primary water stress corrosion cracking

RUB reverse $U$ bend

SCC stress corrosion cracking

sen sensiticed

SG

steam generator 


$\begin{array}{ll}\text { SG-years } & \text { steam generator years } \\ \text { SP } & \text { support plate } \\ \text { Spec } & \text { specification } \\ \text { TS } & \text { tube sheet } \\ \text { TT } & \text { thermally treated } \\ \text { UB } & \text { U bend } \\ \text { UTS } & \text { ultimate tensile strength } \\ \text { WOL } & \text { wedge opening load } \\ \text { YS } & \text { yield strength }\end{array}$




\section{CONTENTS}

1.0 INTRODUCTION $\ldots \ldots \ldots \ldots \ldots \ldots \ldots \ldots \ldots \ldots \ldots \ldots \ldots \ldots \ldots \ldots \ldots \ldots \ldots \ldots \ldots, 1.1$

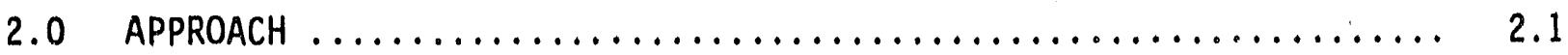

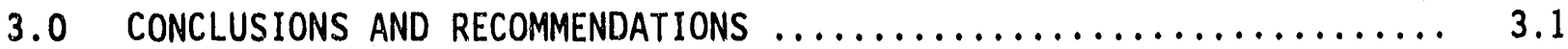

4.0 EVALUATION OF REACTOR. SERVICE EXPERIENCE INVOLVING

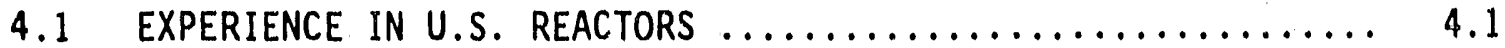

4.2 SPECIFIC COMPARISONS OF SG PERFORMANCE IN
COMPANION REACTORS $\ldots \ldots \ldots \ldots \ldots \ldots \ldots \ldots \ldots \ldots \ldots \ldots \ldots \ldots \ldots$

4.2.1 Catawba Units 1 and $2 \ldots \ldots \ldots \ldots \ldots \ldots \ldots \ldots . \ldots . \ldots . . .4$

4.2 .2 Byron Units 1 and $2 \ldots \ldots \ldots \ldots \ldots \ldots \ldots \ldots \ldots \ldots . .4$

4.2 .3 Other Comparisons $\ldots \ldots \ldots \ldots \ldots \ldots \ldots \ldots \ldots \ldots \ldots \ldots, 4.4$

4.2.4 Summary of Comparisons in Companion Reactors ........ 4.5

5.0 EVALUATION OF LABORATORY TEST RESULTS FOR INCONEL 600

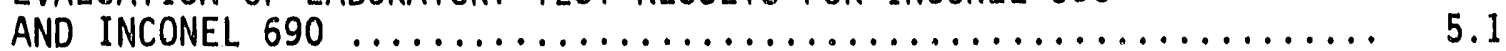

5.1 COMPARISON OF CRACKING PROPERTIES $\ldots \ldots \ldots \ldots \ldots \ldots \ldots \ldots, 5.1$

5.2 SECONDARY SIDE CONSIDERATIONS $\ldots \ldots \ldots \ldots \ldots \ldots \ldots \ldots \ldots, 5.3$

5.3 INFLUENCE OF MICROSTRUCTURE $\ldots \ldots \ldots \ldots \ldots \ldots \ldots \ldots \ldots \ldots \ldots . \ldots \ldots$

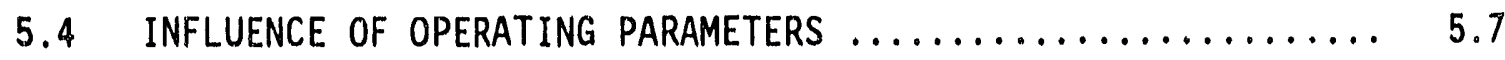

6.0 BASIS FOR ESTIMATING THE SERVICE LIFE OF THE
SEABROOK UNIT 2 SGS $\ldots \ldots \ldots \ldots \ldots \ldots \ldots \ldots \ldots \ldots \ldots \ldots \ldots \ldots \ldots \ldots \ldots$

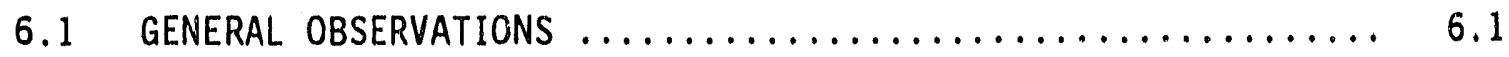

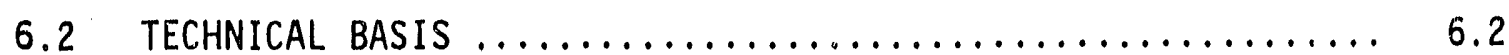

6.3 INDUSTRY COMMENTS REGARDING SG LONGEVITY .............. 6.3

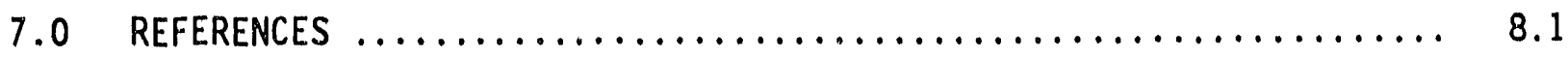

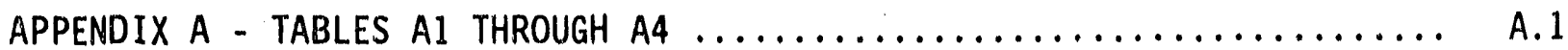




\section{TABLES}

1. Service Experience - Inconel 600 TT and Inconel 690 TT ......... 4.2

2. Characterization of Reactor Experience Base for Alloy 600 TT and Alloy 690 TT SG Tubes in U.S. Reactors ................... 4.3

3. Comparison of Catawba Units - Characteristics and Status ....... 4.5

4. Period Before Cracking in PWR SG Tube Alloys in Simulated Primary Coolant ............................................ 5.3

5. $\mathrm{K}_{\mathrm{I}_{\mathrm{SCC}}}$ for Alloys $600 \mathrm{MA}, 600 \mathrm{TT}, 690 \mathrm{MA}$, and $690 \mathrm{TT}$ in

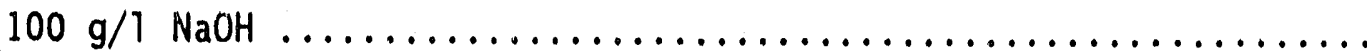

6. Laboratory Experience - Inconel $600 \mathrm{MA}$ and $T T$ and Inconel 690 MA and TT in Reactor Primary Coolant

7. Laboratory Experience - Inconel 690 and Inconel 600 TT in Secondary Fluid

5.5 


\subsection{INTRODUCTION}

After 15 years of operation, the Trojan Series 51 steam generators (SGs) have degraded due to several corrosion mechanisms to the degree that replacement is being considered. The SG tubes are Alloy 600 mill annealed (MA). Appendix A compares properties (Table Al) and corrosion characteristics (Table A2) of candidate tube materials. SG design and operating conditions are briefly outlined in Table A3 for Trojan and Table A4 for Seabrook SGs.

The Bonneville Power Administration (BPA) requested that the Pacific Northwest Laboratory $(P N L)^{(a)}$ evaluate, from a materials standpoint, two options for replacement of the degraded SGs at the Trojan nuclear power plant:

- acquisition of four Model F SGs manufactured in 1981 for the cancelled Seabrook Unit 2 reactor, for near-term installation at Trojan

- acquisition of replacement SGs manufactured with advanced materials and designs, but having a procurement time of 3 to 4 years.

The specific materials issues requested for this assessment are:

- the relative merits of Inconel 600 thermally treated (TT), characteristic of tubes in the Seabrook SGs, versus Inconel 690 TT that is being installed in new SGs

- the basis to project how long the Seabrook SGs can be expected to operate without replacement.

(a) Pacific Northwest Laboratory is operated by Battelle Memorial Institute for the Department of Energy under Contract DE-AC06-76RLO 1830. 


\subsection{APPROACH}

The assessment of SG options focused on:

- reactor service experience for Westinghouse SGs in U.S. plants that have Alloy 600 TT tubes, including plants with replacement SGs and recent plants that began operation with Model F SGs, of the type available in the Seabrook Unit 2 SGs

- reactor service experience for replacement SGs having Alloy 690 TT tubes

- laboratory data for alloy 600 and Alloy 690, emphasizing studies that compared the properties of the two alloys side-by-side

- an overview of Trojan SG characteristics and operation for relevance to expected operation of replacement SGs (Appendix A, Table A3)

- an overview of Seabrook Unit 2 SG characteristics (Appendix A, Table A4). 


\subsection{CONCLUSIONS AND RECOMMENDATIONS}

The relative integrity of Alloy $600 \mathrm{TT}$ and Alloy $690 \mathrm{TT}$ for SG tube application was reviewed, involving two data bases: actual service in SGs and laboratory studies. Conclusions and recommendations from the review are summarized below.

1. Selection of either option: a) Seabrook SGs (with the precautions indicated in point 11 of this section) or b) SGs with advanced designs and Alloy 690 TT tubes seems substantially justified on materials grounds for 20 to 25 years of additional operation at the Trojan reactor. Economic and political considerations, therefore, can enter strongly into the decision process.

2. Alloy 600 TT is in service in about 80 Model F SGs worldwide (about 50 in the U.S.), representing 430 SG-years ${ }^{(a)}$ (290 SG-years in the U.S.). The longest service time is 11 to 12 years. Tube plugging has been minimal $(0.09 \%$ of total tubes plugged due to manufacturing defects, fretting, etc.). No case has been reported of Alloy 600 TT tubes being plugged due to corrosion phenomena in U.S. plants (data for some foreign plants were not found in the review process).

3. Alloy $690 \mathrm{TT}$ is in service in three reactors (two U.S., one Swedish), representing 30 SG-years. The maximum service time is about 3 years. No tube pluggings have been reported for any cause. In the three plants, steam pressures have been lower than expected, possibly due to lower thermal conductivity for Alloy 690 , although other factors may contribute.

4. Numerous laboratory investigations have been published that involved corrosion studies on Alloy 600 and Alloy 690 in multiple metallurgical conditions (Appendix A, Table A2). Laboratory data are available for periods up to four years in primary coolant chemistry and up to eight years in secondary system chemistry. In the studies, Alloy 690 has consistently exhibited superior immunity to stress corrosion cracking (SCC) under pressurized-water reactor (PWR) primary coolant conditions and in normal all volatile treatment (AVT) conditions. Alloy 690 also has superior corrosion and cracking resistance in secondary side upset chemistry conditions. Extrapolation of accelerated test results suggests that SGs with Alloy 600 TT could provide up to 20 to 25 years of service and Alloy 690 (MA or TT) could provide up to 30 to 35 years of service.

5. Alloy 690 has emerged as the solid leader in corrosion and cracking resistance in laboratory tests. Alloy 600 TT has ihe more substantial

(a) $\quad S G$-year = steam generator year, i.e., one $S G$ in service (at power or shut down) for one year. 
reactor service history. Both Alloy 690 TT and Alloy 600 TT have superior laboratory corrosion resistance to Alloy 600 MA that has had a poor history of performance in SG applications, including service in the Trojan SGs.

6. The emerging impressive reactor performance of SGs with Alloy 600 TT tubes (i.e., no corrosion-induced tube plugging in up to 11 years of service time) must be interpreted not just in terms of improved material properties, but also reflecting improved crevice design, support plate and tube sheet materials, and water chemistry control, among other factors.

7. The reactor performance of Alloy 690 TT has also been successful, but it would be premature to base long-term decisions on current, limited, short term results under reactor service conditions. However, combined with superior performance in extensive laboratory tests, Alloy 690 TT has numerous proponents as the material of choice for extending the successful operation of SGs. Other investigators recommend caution until the reactor data base is more extensive.

8. While the Alloy 600 TT and 690 TT tube materials have performed well in laboratory tests under upset chemistry conditions, behavior of the advanced SG materials and designs under upset conditions has not yet been substantially challenged in reactor service.

9. The emerging successful performance of Model F SGs and improved laboratory corrosion performance of Alloy 600 TT (compared to Alloy $600 \mathrm{MA}$ ) suggest that the Seabrook Unit 2 Model $F$ SGs have validity as replacement candidates for the degraded Trojan SGs. With now over a decade of Model F SG service without tube plugging due to corrosion, satisfactory service times of 20 to 25 years seem possible, though not assured (depending on the response to serious upsets and possible impacts of other Seabrook SG vulnerabilities).

10. From a materials standpoint, the following considerations must be weighed:

- Is there sufficient evidence for confidence that the Seabrook SGs will provide satisfactory service at Trojan through the current 40-year 1icense period ( 25 more years)? The positive service performance of Mode1 F SGs for over a decade and superior behavior of Alloy $600 \mathrm{TT}$ materials in laboratory tests, compared to Alloy $600 \mathrm{MA}$, offer favorable evidence that satisfactory operation of Model F SGS is a reasonable expectation for periods of 20 to 25 years, given nominal operating conditions (e.g., temperatures) and satisfactory water chemistry control. It seems premature to also project satisfactory performance of Model F SGs through the 1 icense renewal period (up to 20 years beyond the current 40 -year license), if that is a consideration for the Trojan reactor.

- Is there sufficient evidence for confidence that SGs with Alloy 690 tubes will provide satisfactory service through the remaining 
25 years of the current 40-year license period? Also, through up to 20 years of additional service in extended operation? The principal bas is for judgement of Alloy 690 TT behavior is extensive laboratory testing. Because Alloy 690 specimens did not fail in laboratory tests, a bound is not established. Our extrapolation of the laboratory data from $360^{\circ} \mathrm{C}$ to $330^{\circ} \mathrm{C}$ (near the Trojan hot leg temperature of $325^{\circ} \mathrm{C}$ ) suggested that the specimens would remain unfailed after 30 years. The limited service experience with Alloy 690 TT tubes in SGs does not contribute substantially to the basis for extrapolation. However, the favorable experience with the improved design and operation of Model $F$ SGs seems relevant. If the Model F SGs had been tubed with Alloy 690 TT tubes, the laboratory data suggest that the performance would have been without corrosion-induced failures as has been the case with Alloy 600 TT tubes. Therefore, the basis for optimism for Model F SG to operate through the remainder of the current Trojan license seems equally justified for units tubed with Alloy $690 \mathrm{TT}$. There is insufficient evidence that Alloy $690 \mathrm{can}$ be relied on for current operation plus the full term of license renewal.

11. A decision regarding the Seabrook SG units should factor in other considerations, including the following:

- Have lay-up conditions during over a decade of storage been adequate to preclude degradation?

- What over-checks on materials are warranted to assure that specifications are uniformly met throughout the SGs?

- Has the Seabrook SG design been analyzed sufficiently for deficiencies (e.g., character of quatrefoil broaches, Alloy $600 \mathrm{com}-$ ponents such as drains and channel divider plate, and anti-vibration bar and flow baffle design)?

- Have the prospects for, and consequences of, prospective upgrades (e.g., replacement of carbon steel $\mathrm{J}$ tubes and flow ring) been adequately considered?

- Are the projected operating conditions for the replacement SGs at Trojan within the envelope of conditions (e.g., temperature and water chemistry) that have been conducive to highly favorable service performance of Model F SGs? 


\subsection{EVALUATION OF REACTOR SERVICE EXPERIENCE INVOLVING ALLOY 600 TT AND ALLOY 690 TT SG TUBES}

Corrosion-induced faitures of tubes in original PWR SGs has been a costly and troublesome problem. That experience contrasts with vastly improved performance of new and replacement SGs that have improved designs and materials. The favorable service experience is summarized in this section.

\subsection{EXPERIENCE IN U.S. REACTORS}

Reactor service for three groupings of SGs is summarized in Table 1.

A. Replacement SGs with Alloy 600 TT tubes installed in U.S. reactors

B. Original SGs of Type F and D5 with A1loy 600 TT cubes installed in U.S. reactors

C. Replacement SGs with Alloy 690 TT tubes at two U.S. reactors and one Swedish reactor

Key features of the reactor experience base are provided in Table 1 for Alloy $600 \mathrm{TT}$ and Alloy $690 \mathrm{TT}$, and are summarized in Table 2. The longest service is about 11 years for Alloy 600 TT tubes (in 1992) and about 3 years for Alloy 690 TT.

From Table 2, the cumulative service time for SGs with Alloy 600 TT tubes operating in U.S. plants is 290 SG-years. The corresponding number for SGs with Alloy 690 tubes is about 30 SG-years. (a)

Tube plugging data (Dow 1991) indicate that no tubes were plugged due to any corrosion mechanism for the SGs addressed in Table 1 . The significance of that observation is that corrosion-induced tube plugging was prevalent in early operation of numerous SGs. For example, tube plugging due to corrosion began after 2 years in Surry Unit 1 and after 1 year in Surry Unit 2 for the

(a) There are 84 Model F SGs worldwide with operational experience, representing 432 SG-years of service. In 1991 only $0.09 \%$ of the tubes had been plugged, involving less than 1 tube plugged per SG per year of operation. Most. out not all tubes in Model F SGs are Alloy $600 \mathrm{TT}$. For example, in Callaway, both TT (first 10 rows) and MA conditions are represented. 


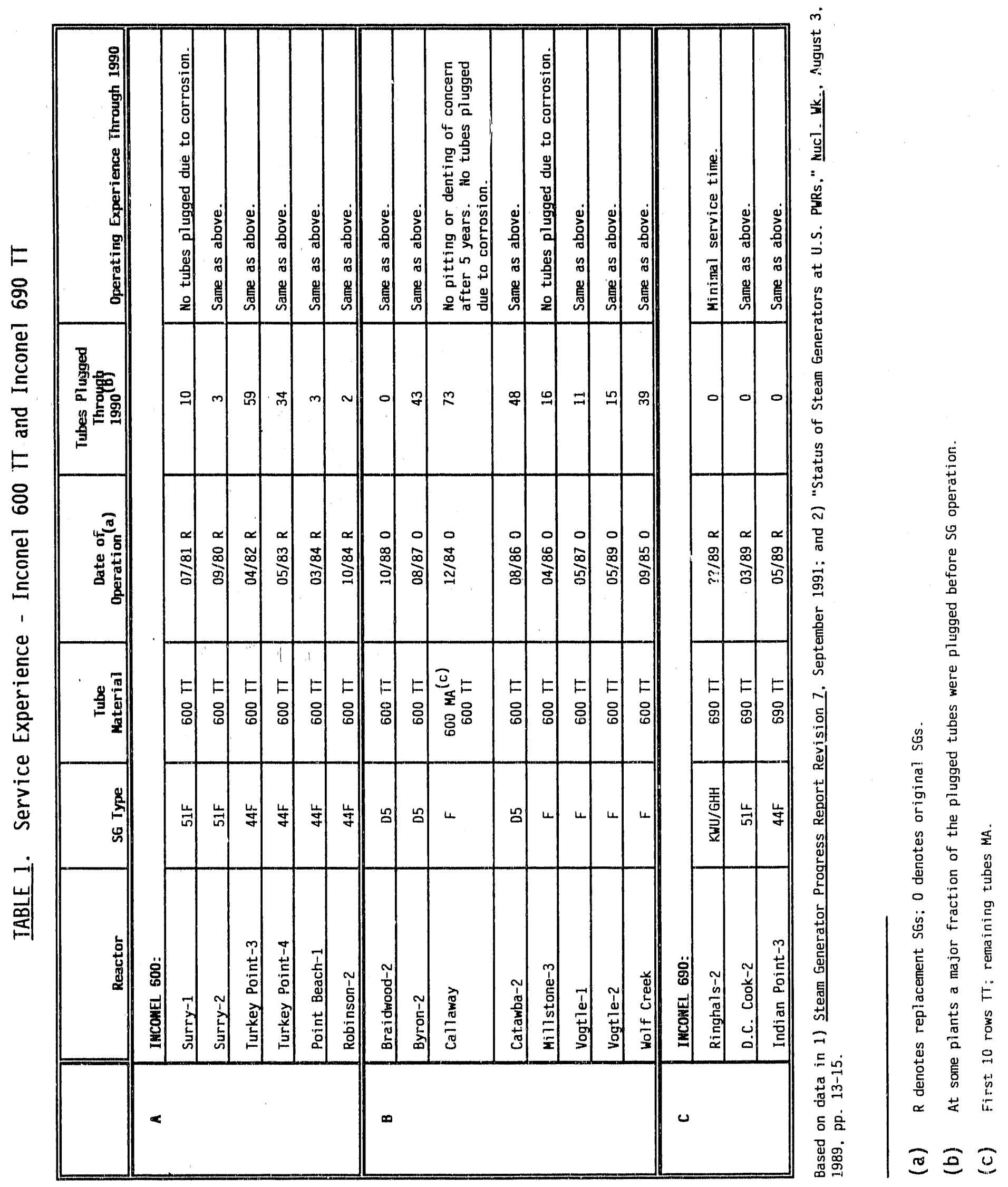


TABLE 2. Characterization of Reactor Experience Base for A1loy 600 TT and Alloy 690 TT SG Tubes in U.S. Reactors

I. Longest Service Time (Through Early 1992)

Alloy $600 \mathrm{TT}$ : original SG is 7 years; replacement SG is 11 years

Alloy 690 TT: replacement SG is 3 years

II. Total Service Time (Through Early 1992)

$\begin{array}{lll}\text { No. of } & \text { No. of } & \text { Toial Service } \\ \text { Reactors }^{(a)} & \underline{S G S} & \text { Iime, SG-Years }\end{array}$

A110y 600 TT $\quad 13 \quad 49 \quad 290$

$\begin{array}{llll}\text { A1loy } 690 & T^{(b)} & 11 & 30\end{array}$

III. Iubes Plugged Due to Corrosion (Through 1990)

Alloy 600 TT: zero

Alloy 690 TT: zero

(a) Westinghouse reactors at U.S. plants for Alloy 600 TT.

(b) Two U.S. and one Swedish reactors.

original SGs. Similar comparisons are valid for other reactors having replacement SGs. However, for the replacement SGs, no tubes have been plugged due to corrosion through 1990 (after; 9 and 10 years, respectively).

The absence of corrosion-induced plugging results from numerous factors, including (but not limited to) improved water chemistry, removal of secondaryside copper sources, improved sludge management, improved SG design, and materials, including 400-series tube sheets and support plates, and more corrosion-resistant tube materials.

The three reactors operating with Alloy 690 SG tubes have reported steam pressures that are less than expected, resulting in a concomitant decrease in power production. The phenomenon is hypothesized to be due to lower thermal conductivity for Alloy 690, compared to Alloy 600 (see Table Al). However, other factors may contribute to the lower steam pressures (Nucleonics Week et a1. 1990). 


\subsection{SPECIFIC COMPARISONS OF SG PERFORMANCE IN COMPANION REACTORS}

Comparisons of SG performance in companion reactors can be instructive, but conclusions must be drawn with caution due to potential differences in SG design and operating conditions. In most cases, the comparisons are drawn between SGs with Alloy 600 MA tubes in one plant and Alloy 600 TT tubes in the companion plant.

\subsubsection{Catawba Units 1 and 2}

The characteristics and status of the two Catawba units are compared in Table 3. Catawba Unit 1 has had both inner diameter (ID) and outer diameter (OD) corrosion indications while Catawba Unit 2 has not plugged tubes due to corrosion. Catawba Unit 1 has operated one year longer, but began to show corrosion indications after only 2 to 3 years. Catawba Unit 2 has not plugged tubes due to corrosion after 3 to 4 years.

A comparison of properties for tubes in the Catawba SGs revealed substantial differences that reportedly resulted from a thermal treatment that was shorter than specified for one batch of tubes.

The absence of corrosion indications for Catawba Unit 2 is consistent with improved design and higher integrity materials (Table 3).

\subsubsection{Byron Units 1 and 2}

Byron Unit 1 (09/85 operation) has A1loy 600 MA SG tubes, a carbon steel support plate, and drilled support plate holes; while Byron Unit 2 (08/87 operation) has Alloy 600 TT SG tubes, a stainless steel support plate, and a quatrefoil support plate crevice. Through 1990, Byron Unit 1 has plugged 43 tubes due to ID corrosion indications while Byron Unit 2 has not plugged tubes due to corrosion, but began operation two years later.

\subsubsection{Other Comparisons}

Braidwood Units 1 and 2 began operation in 1988 . The SG tubes are Alloy $600 \mathrm{MA}$ at Unit 1 and Alloy $600 \mathrm{TT}$ at Unit 2. Neither unit has plugged tubes for corrosion reasons, but the operating time is relatively short.

Cook Unit 1 (08/75 operation) stil1 operates with the original Model 51 SGs (713 tubes plugged due to corrosion). The Cook Unit 2 Model 51 SGs were 
replaced in 1988 (561 tubes plugged due to corrosion and 378 due to other causes) with Mode 151 SGs with Alloy $690 \mathrm{TT}$ tubes. The higher susceptibility of the Cook Unit 1 tubes to ID SCC was regarded by a company spokesman as due to a difference in SG fabrication (NuCl. Wk., August 3, 1988).

\subsubsection{Summary of Comparisons in Companion Reactors}

In general, the operating times for SGs addressed in the above comparisons of plant pairs are not long enough to draw major conclusions. However, to date, tube plugging due to corrosion has been necessary for most units having older designs and materials and has been essentially zero for newer designs and matertals.

TABLE 3. Comparison of Catawba Units - Characteristics and Status

\begin{tabular}{||l|l|l||}
\hline \multicolumn{1}{|c|}{ Characteristic } & Catawba Unit 1 Status & Catawba Unit 2 Status \\
\hline \hline Initial operation & $6 / 85$ & $8 / 86$ \\
\hline SG model & D3 & 05 \\
\hline Tube materiai & $600 \mathrm{MA}$ & $600 \mathrm{TT}$ \\
\hline Tube support material & Carbon steel & Stainless steel \\
\hline Support plate hole & Drilled holle & Quatrefoil \\
\hline Tube/tube sheet & Full/roll & Fu11/hydro \\
\hline Tube plugging: & & \\
(a) & & \\
OD S/IGA SP & 17 & 0 \\
: ID SCC TS & 193 & 0 \\
ID SCC UB & 1 & 0 \\
Fret (Preh) & 3 & 14 \\
Fret (AVB) & 0 & 10 \\
Fret (LP) & 0 & 24 \\
Other (non- & 42 & \\
corrosion) & & \\
\hline
\end{tabular}

(a) Through 1990. 


\subsection{EVALUATION OF LABORATORY TEST RESULTS FOR INCONEL 600 AND INCONEL 690}

Laboratory testing has been conducted primarily under conditions of constant stress, constant strain rate, stressed $C$-ring tests, reverse $U$-bend tests, and pressurized tubes. The objectives of these tests have been to characterize the degradation phenomena of 1) primary water stress corrosion cracking (PWSCC) at roll transitions, $U$-bends, and dents of recirculating steam generators, 2) secondary side intergranular attack/stress corrosion cracking (IGA/SCC) at tube supports, in tube sheet crevices, and in sludge piles of recirculating steam generators, and 3) erosion-corrosion in oncethrough steam generators. These tests have been conducted in controlled water at temperatures ranging from $360^{\circ} \mathrm{C}$ to $400^{\circ} \mathrm{C}$ in steam; these temperatures are higher than typical hot leg temperatures in steam generators and, therefore, are considered to be accelerated tests. The importance of accelerated tests is that testing and steam generator experience with Incone 690 is limited to eight and less than five years, respectively. Accelerated tests provide early comparative information, but do not directly predict service 1ifetimes.

\subsection{COMPARISON OF CRACKING PROPERTIES}

As indicated in Section 3, cracking of Inconel 690 TT or 600 TT has not been observed through the latest reported inspections (1990) under steam generator service conditions. Inconel 690 TT and MA appears to be superior to Inconel 600 TT and MA in most mechanical and corrosion laboratory tests. The thresholds for cracking in Inconel 690 MA and TT have only been detectable in accelerated tests or under abnormally severe test conditions. Under primary water conditions, the threshold for cracking in Inconel 690 TT appears to be unbounded. Cracking from the secondary side may be the limiting factor. However, the data base is insufficient to quantitatively characterize the performance margin of Inconel 690 TT over Inconel 600 TT in terms of SG years. A summary of French and other work on SCC of SG tubing materials has been provided by Gras (1991). McIlree, 0lberg and Nestell (1985) have published a steam generator reference book.

Reverse U-bend (RUB) specimens tested for periods up to 33,000 hours to show time to cracking (Norring, Stiller, and Nilsson 1991) indicate that the 
cracking resistance of Inconel $690 \mathrm{MA}$ and $690 \mathrm{TT}$ is superior to that for Inconel $600 \mathrm{TT}$ which is superior to Inconel $600 \mathrm{MA}$. The results are summarized in Table 4. Tests with Alloys 600 TT and 690 TT extended only to 23,000 hours. Because the test temperatures are higher than the Trojan hot leg temperature, these represent accelerated tests. When these results were extrapolated to $330^{\circ} \mathrm{C}$ (near the Trojan hot leg temperature of $325^{\circ} \mathrm{C}$ ) using the temperature dependence for initiation of crack propagation given by Gras (1991), then the predicted period to the onset of cracking was extended longer, also shown in Table 4.

The extrapolation is based on the relationship given by Gras:

$$
t_{0}=A \exp (22000 / T)
$$

where $t_{0}$ is the time-to-cracking evolution and $T$ is temperature in Kelvin. The extrapolation is based primartly on data for Inconel 600 MA. The value of A depends on microstructure, microchemistry, stress and strain history, heat exchanger design features, hot leg temperature, and water chemistries of the primary and secondary systems. The reliability of an extrapolation from the test temperature to the Trojan hot leg temperature is al so subject to unknown factors, e.g., variability in the performance of sibling steam generators operated similarly at companion nuclear plants. However, Equation 1 provides a basis for evaluating the potential for performance improvement offered by the Inconel $690 \mathrm{TT}$ over the Inconel $600 \mathrm{TT}$.

TABLE 4. Period Before Cracking in PWR SG Tube Alloys in Simulated Primary Coolant

\begin{tabular}{||l|c|c|}
\hline \multirow{2}{*}{ Alloy } & \multicolumn{2}{|c|}{ Period Before Cracking, hours } \\
\cline { 2 - 3 } & $365^{\circ} \mathrm{C}$ Data & $330^{\circ} \mathrm{C}$ Predicted \\
\hline \hline Incone1 600 MA & 1,000 to 11,000 & 7,000 to 80,000 \\
\hline Incone1 600 TT & $23,000^{(\mathrm{a})}$ & 170,000 \\
\hline Incone1 690 TT & $>23,000^{(\mathrm{b})}$ & $>170,000$ \\
\hline Incone1 690 MA & $>33,000^{(\mathrm{b})}$ & $>240,000$ \\
\hline
\end{tabular}

(a) Cracks were found in two of four specimens.

(b) No cracks were found. 
The comparison of Inconel $690 \mathrm{MA}$ and TT to Inconel $600 \mathrm{MA}$ and TT in Table 4 predicts cracking in Inconel $600 \mathrm{MA}$ between one and ten years. This is similar to service history. The period of extrapolated data representing about 20 years $(170,000$ hours) for A1loy 600 TT (two of four specimens cracked at the $360^{\circ} \mathrm{C}$ test temperature) is not verified by experience, because the oldest steam generator with Alloy 600 TT tubes has only operated for approximately 10 years. However, the 20-year extrapolation is not inconsistent, because no Alloy 600 TT tubes have bean plugged due to cracking in up to 10 years of reactor service.

The comparison may be conservative, because the tests were not conducted long enough to produce cracking in the Inconel 690 specimens. Comprehensive data bases on the temperature dependence for crack initiation for the thermally treated Inconel 600 and 690 alloys do not appear to be avallable. The results for Inconel 690 MA are included in Table 4 because they imply that even if Inconel 690 components were not uniformly heat treated, the resistance to cracking would likely exceed that for the Inconel 600 alloy.

\subsection{SECONDARY SIDE CONSIDERATIONS}

The values of threshold stress intensity, $K_{I_{S c C}}$, obtained from Alloy 690 wedge opening load (WOL) specimens in caustic weres significantly higher than for Inconel 600 based on a summary by Gold et al. (1990). The results are shown in Table 5 . In a solution with a lower caustic concentration, $4 \mathrm{~g} / \mathrm{L}$ $\mathrm{NaOH}$, the threshold stress intensity nearly doubled for Inconel 600 MA and TT, but cracking was not propagated in Inconel 690 MA or TT. The threshold stress intensity defines the load condition required to propagate cracking.

The test data in reactor primary coolant with the longest duration extend to approximately 4 years (Table 6 ). The test data in secondary steam generator water with the longest duration extend to approximately 8 years (Table 7). Because of limited testing time, some tests were conducted under extreme temperature, stress, strain rate, or chemically concentrated conditions. These conditions represent accelerated tests. The number of the longest term tests had limited scope and, therefore, do not provide a broad 
TABLE 5. $\quad \mathrm{K}_{\mathrm{I}_{\mathrm{SCC}}}$ for A1loys $600 \mathrm{MA}, 600 \mathrm{TT}, 690 \mathrm{MA}$, and $690 \mathrm{TT}$ in $100 \mathrm{~g} / \mathrm{L}$ $\mathrm{NaOH}$ (Gold et al. 1990)

\begin{tabular}{|c|c|}
\hline Inconel Alloy and Condition & $K_{\mathrm{I}_{S C C}, p s i-i n^{0.5} \text { in } 100 \mathrm{~g} / \mathrm{L} \mathrm{NaOH}}$ \\
\hline $600 \mathrm{MA}$ & 8,300 \\
\hline $600 \mathrm{TT}$ & 11,600 \\
\hline $690 \mathrm{MA}$ & 14,800 \\
\hline $690 \mathrm{TT}$ & 21,100 \\
\hline
\end{tabular}

TABLE 6. Laboratory Experience - Inconel $600 \mathrm{MA}$ and TT and Inconel $690 \mathrm{MA}$ and TT in Reactor Primary Coolant

\begin{tabular}{|c|c|c|c|c|c|}
\hline $\begin{array}{l}\text { Inconol } \\
\text { Alloy }\end{array}$ & $\begin{array}{c}\text { Test } \\
\text { Period, } h\end{array}$ & rest Type & Summary of Results & Solution & Reference \\
\hline $\begin{array}{l}600 \mathrm{MA} \\
600 \mathrm{TT} \\
690 \mathrm{MA} \\
690 \mathrm{TT}\end{array}$ & $\begin{array}{r}<11,000 \\
23,000 \\
>33,000 \\
>23,000\end{array}$ & $\operatorname{RUB}^{(a)}$ & $\begin{array}{c}600 \mathrm{TT}: 2 \text { of } 4 \text { speoimens } \\
\text { craoked within } 23000 \mathrm{~h} \\
690 \mathrm{MA} \text { not oracked in } \\
33,000 \mathrm{~h}: 690 \mathrm{TT} \text { not oracked } \\
\text { in } 23,000 \mathrm{~h}\end{array}$ & $\begin{array}{c}365^{\circ} \mathrm{C} \text { water } \\
\text { with } \\
\text { hydrogen }\end{array}$ & $\begin{array}{l}\text { Norring, } \\
\text { Sttller, and } \\
\text { Ntlsson, } 1991\end{array}$ \\
\hline $\begin{array}{l}690 \mathrm{MA} \\
690 \mathrm{TT}\end{array}$ & $\begin{array}{l}16,000 \\
16,000\end{array}$ & RUB & Observed no cracking. & $\begin{array}{l}360^{\circ} \mathrm{C} \\
\text { primary } \\
\text { water }\end{array}$ & $\begin{array}{l}\text { Smith et } \mathrm{al} \text {. } \\
1985\end{array}$ \\
\hline $\begin{array}{l}690 \mathrm{MA} \\
690 \mathrm{TT}\end{array}$ & $\begin{array}{l}12,000 \\
12,000\end{array}$ & RUB & Observed no craoking & $\begin{array}{l}360^{\circ} \mathrm{C} \\
\text { primary } \\
\text { water }\end{array}$ & $\begin{array}{l}\text { Gimond et al. } \\
1985\end{array}$ \\
\hline $\begin{array}{l}690 \mathrm{MA} \\
690 \mathrm{TT}\end{array}$ & $\begin{array}{l}10,000 \\
10,000\end{array}$ & RUB & Observed no cracking & $\begin{array}{l}360^{\circ} \mathrm{C} \\
\text { primary } \\
\text { water } \\
\end{array}$ & $\begin{array}{c}\text { Yonezawa et } \\
\text { a). } 1.985\end{array}$ \\
\hline $690 \mathrm{TT}$ & 4000 & RUB & No cracking & $\begin{array}{c}400^{\circ} \mathrm{C}, 3000 \\
\text { psi steam } \\
\text { with } \\
\text { hydrogen }\end{array}$ & $\begin{array}{c}\text { Aspden et al. } \\
198\end{array}$ \\
\hline $690 \mathrm{MA}$ & 7200 & RUB & to cracking & $400^{\circ} \mathrm{C}$ steam & $\begin{array}{c}\text { Gold et al. } \\
1990\end{array}$ \\
\hline $\begin{array}{l}690 \mathrm{MA} \\
690 \mathrm{TT}\end{array}$ & 31.000 & RUB & No cracking & $\begin{array}{c}360^{\circ} \mathrm{C} \text { water } \\
\text { with } \\
\text { hydrogen }\end{array}$ & $\begin{array}{l}\text { Santarini et } \\
\text { al. } 1989\end{array}$ \\
\hline $\begin{array}{l}690 \mathrm{MA} \\
690 \mathrm{TT} \\
\end{array}$ & 6,000 & RUB & No oracking & $400^{\circ} \mathrm{C}$ steain & $\begin{array}{c}\text { Santarini et } \\
\text { al. } 1989 \\
\end{array}$ \\
\hline $\begin{array}{l}600 \mathrm{MA} \\
.690 \mathrm{TT}\end{array}$ & 1500 & $\begin{array}{l}\text { Dissolution by } \\
\text { corrosion }\end{array}$ & $\begin{array}{l}600 \mathrm{MA} \text { oorrosion } 4 \text { to } 6 \\
\text { times higher than for } 690 \mathrm{TT}\end{array}$ & $\begin{array}{l}330^{\circ} \mathrm{C} \\
\text { primary } \\
\text { coolant }\end{array}$ & $\begin{array}{l}\text { Gold et al. } \\
1990\end{array}$ \\
\hline
\end{tabular}

(a) Reverse $U$ bend test. 
IABLE 7. Laboratory Experience - Inconel 690 and Inconel $600 \mathrm{TT}$ in Secondary Fluid

\begin{tabular}{|c|c|c|c|c|c|}
\hline $\begin{array}{l}\text { Inconel } \\
\text { Alloy }\end{array}$ & $\begin{array}{c}\text { Test } \\
\text { Period, } \\
\text { h }\end{array}$ & Test Type & Summary of Results & Solution & $\begin{array}{l}\text { Refer- } \\
\text { ence }\end{array}$ \\
\hline $\begin{array}{l}600 \mathrm{MA} \\
600 \mathrm{TT} \\
690 \mathrm{MA} \\
690 \mathrm{TT} \\
\end{array}$ & $:$ & $\begin{array}{l}\text { WOL (a) speci- } \\
\text { mens tested } \\
\text { in caustic } \\
\text { solutions }\end{array}$ & $\begin{array}{l}\text { Threshold stress } \\
\text { intensity highest } \\
\text { for } 690 \mathrm{MA} \text { and TT }\end{array}$ & $\begin{array}{l}350^{\circ} \mathrm{C} \\
200^{\mathrm{g} / \mathrm{L}} \\
\mathrm{NaOH}\end{array}$ & $\begin{array}{l}\text { Smith et } \\
\text { a1. } 1985\end{array}$ \\
\hline $690 \mathrm{TT}$ & 76,000 & C-Ring & No cracking & $\begin{array}{l}\text { Numerous } \\
\text { caustic } \\
\text { solutions }\end{array}$ & $\begin{array}{l}\text { Smith et } \\
\text { a1. } 1985\end{array}$ \\
\hline $690 \mathrm{TT}$ & & $\begin{array}{c}\text { Pressurized } \\
\text { capsules }\end{array}$ & No cracking & $\begin{array}{l}\text { Numerous } \\
\text { caustic } \\
\text { solutions }\end{array}$ & $\begin{array}{l}\text { Smith et } \\
\text { a1. } 1985\end{array}$ \\
\hline $690 \mathrm{TT}$ & 12,000 & $R^{\prime} B^{(b)}$ & No cracking & $\begin{array}{c}350^{\circ} \mathrm{C} \quad 10 \% \\
\mathrm{NaOH}\end{array}$ & $\begin{array}{l}\text { Santart- } \\
\text { ni et } \\
\text { a1. } 1989\end{array}$ \\
\hline $690 \mathrm{TT}$ & 12,000 & C-Ring & No cracking & $\begin{array}{c}350^{\circ} \mathrm{C} \quad 10 \% \\
\mathrm{NaOH}\end{array}$ & $\begin{array}{l}\text { Santari- } \\
\text { ni et } \\
\text { al. } 1989\end{array}$ \\
\hline $690 \mathrm{TT}$ & 4,000 & C-Rings & No cracking & $\begin{array}{l}288 \text { to } \\
300^{\circ} \mathrm{C} \\
\text { acid } \\
\text { chloride }\end{array}$ & $\begin{array}{c}\text { Yonezawa } \\
\text { et al. } \\
1985\end{array}$ \\
\hline $690 \mathrm{TT}$ & 4,000 & RUB & No cracking & $\begin{array}{l}288 \text { to } \\
300^{\circ} \mathrm{C} \\
\text { acid } \\
\text { chloride }\end{array}$ & $\begin{array}{c}\text { Yonezawa } \\
\text { et al. } \\
1985\end{array}$ \\
\hline $690 \mathrm{TT}$ & 1500 & $\begin{array}{l}\text { C-Rings } \\
150 \% \text { YS }^{(c)}\end{array}$ & No cracking & $\begin{array}{c}343^{\circ} \mathrm{C} \quad 10 \% \\
\mathrm{NaOH}\end{array}$ & $\begin{array}{c}\text { Yonezawa } \\
\text { et al. } \\
1985\end{array}$ \\
\hline $\begin{array}{l}690 \mathrm{TT} \\
690 \mathrm{MA}\end{array}$ & 36,790 & RUB & No cracking & $\begin{array}{l}288 \text { to } \\
360^{\circ} \mathrm{C} \text { in } \\
A V T^{(d)} \\
\text { water }\end{array}$ & $\begin{array}{l}\text { EPRI } \\
\text { NP-576- } \\
1 S P\end{array}$ \\
\hline $\begin{array}{l}690 \mathrm{TT} \\
690 \mathrm{MA}\end{array}$ & 71,000 & C-Rings & No cracking & $\begin{array}{l}288 \text { to } \\
343^{\circ} \mathrm{C} \text { in } \\
\text { AVT water }\end{array}$ & $\begin{array}{c}\text { EPRI } \\
\text { NP-5761S }\end{array}$ \\
\hline
\end{tabular}
(a) Wedge ovening load.
(b) Reverse $U$ bend test.
(c) Yield strength.
(d) All volatile treatment. 
statistical data base. However, the differences between Inconel 600 and 690 appear to be significant, even with the limited data base. The WOL value was higher for Alloy $690 \mathrm{TT}$ than for Alloy $600 \mathrm{TT}$ at $350^{\circ} \mathrm{C}$ in $200 \mathrm{~g} / \mathrm{L}$ caustic (Smith et a1. 1985). Procedures to extrapolate for longevity predictions under service conditions are complex and may be misleading because of the many variables in material condition and operating parameters that may not be adequately accounted for. These comments also apply to the predictions made in Table 4. Therefore, control of plant operation may be nearly as important as the selection of an alloy.

Accelerated dissolution corrosion tests have failed to reveal a superiority of Alloy 690 over Inconel 600. Wastage in Inconel 690 exceeded wastage in Alloy 600 during accelerated testing of stressed $C$ rings in solutions containing acid sulfates, with or without chlorides (Cullen et al. 1991). Likewise Alloy 690 suffers wastage similar to Alloy 600 in organic acid solutions. Therefore, the relative benefits of Alloy 690 over Alloy 600 characteristic of tests in primary coolant conditions are less favorable for some conditions that simulate upset secondary water chemistries.

\subsection{INFLUENCE OF COMPOSITION AND MICROSTRUCTURE}

Improved resistance to cracking in alloys containing more than $18 \%$ chromium $(\mathrm{Cr})$ has been the reason for manufacturing and research on a modified Alloy 600 with $19 \% \mathrm{Cr}$. This alloy behaves better than normal Alloy 600 (Donati et a1. 1987). The higher $\mathrm{Cr}$ content is likely an important factor for the superior performance of Alloy 690. The higher $\mathrm{Cr}$ content may play a role in providing a passive surface that is more resistant to hydrogen and impurity species. Factors that affect the corrosion and cracking resistance include (but are not restricted to):

- carbon and $\mathrm{Cr}$ concentrations and distribution (heat treatment)

- residual stresses from fabrication and incomplete weld sections (stress relief)

- high temperature mill anneal (best for Inconel 600, but stil1 susceptible)

- low temperature mill anneal 
- low angle grain boundaries better than intermediate and high angles (Crawford and Was 1991)

Laboratory testing has indicated that the yield stress for thermally treated Inconel 690 should not exceed 56,000 psi (Amar and Shah 1991). This upper limit on yield stress tends to reduce the potential for cracking by limiting deleterious cold working and residual stresses.

\subsection{INFLUENCE OF OPERATING PARAMETERS}

In addition to water chemistry parameters ilready addressed, other operating parameters have been recognized to have important effects on heat exchanger degradation. Variables in operating parameters that may impact service longevity are:

- Low lead (Sakai et al. 1991); the corrosion of annealed Alloy 600 and thermally treated Alloy 690 was increased by lead, but the corrosion of Alloy 690 tended to be more transgranular, rather than intergranular. (Migl in et al. 1991); Accelerated tests with Inconel 600 MA C-ring specimens in water enriched with lead at $360^{\circ} \mathrm{C}$ indicated that lead induces and propagates cracking.

- Zinc addition (Esposito et al. 1991); addition of $20 \mathrm{ppb}$ zinc decreased the corrosion rate for $600 \mathrm{TT}$ and 690 TT and increased the crack initiation times for $600 \mathrm{MA}$ and 600 TT by factors of up to four during highly stressed reverse U-bend testing.

- Hot leg temperature; the kinetics of degradation phenomena are increased with increasing hot leg temperature. 


\subsection{BASIS FOR ESTIMATING THE SERVICE LIFE OF THE SEABROOK UNIT 2 SGS}

The basis to estimate the service life of the Seabrook Unit 2 Model $F$ SGs depends on the past decade of highly favorable Model F SG service, results of extensive laboratory testing, and our extrapolation of the laboratory results to the Trojan hot leg temperature $\left(325^{\circ} \mathrm{C}\right)$. Several caveats are identified that might influence the $S G$ performance.

\subsection{GENERAL OBSERVATIONS}

Estimates of SG service life were frustrating in the decades of the 1960 s and 1970s. Tube plugging due to corrosion began in the early years of operation and multiplied in many units to a magnitude requiring costly replacements.

Now there is emerging evidence that the factors that determine SG integrity may be largely understood and under control. That evidence is represented in part by the service experience summarized in Table 2 . Units have operated for up to a decade without tube plugging due to corrosion.

However, while there is a growing basis for optimism, this is also a time for cautions and caveats.

- While AVT chemistry has mitigated denting, the lack of buffering action leaves crevices potentially vulnerable to $\mathrm{pH}$ excursions into corrosive regimes. The optimum approach to water chemistry control, use of inhibitors, etc., may not yet have fully emerged. However, incorporation of improved crevice designs mitigates crevice corrosion.

- The resistance of the advanced designs and materials to severe episodes of impurity ingress seems yet to be tested, even though laboratory studies indicate that advanced tube materials are more resistant to faulted secondary-side conditions than the Alloy 600 MA material (Appendix A, Tabie A2).

- Indications that some SG materials have not fallen uniformly within specifications suggests that units such as Seabrook Unit 2 reed to undergo sufficient scrutiny and perhaps over-checks to ensure that potential vulnerabilities are recognized. Other areas to be considered are anti-vibration bar and flow baffle design, flow ring and J-tube materials, and the long-term behavior of Inconel components other than the tubes (e.g., drains and channel divider plate). 
- Some reactor staff, with management support, have given high priority to rapidly correcting upset chemistry conditions, sometimes at the expense of power production. The lifetime of a given set of SGs will be influenced by management philosophy and staff diligence.

\subsection{TECHNICAL BASIS}

The data bases reviewed in Sections 4 and 5 have the following relevance to the Seabrook Unit 2 SG units:

- The Seabrook units are Model F SGs that relate to the substantial and, so far, successful experience summarized in Section 4.

- The Seabrook units are tubed with Alloy 600 TT that has markedly improved corrosion resistance, compared to early Alloy 600 metallurgical conditions, based on comparative laboratory corrosion tests summarized in Section 5.

Extrapolation of laboratory data was conducted from a study of primaryside SCC and conducted at $360^{\circ} \mathrm{C}$ on four specimen categories: Alloy $600 \mathrm{MA}$ and $\mathrm{TT}$; and Alloy $690 \mathrm{MA}$ and TT. The data were extrapolated to $330^{\circ} \mathrm{C}$, near the maximum Trojan hot leg temperature of $325^{\circ} \mathrm{C}$. Cracking for $600 \mathrm{MA}$ condition was estimated to occur in the period of 1 to 10 years, consistent with $S G$ reactor service experience. The 600 TT condition estimate suggested that cracking could be expected to begin at about 20 years. The data for 690 TT was extrapolated to 20 years without cracking, and for 690 MA the extrapolation was 30 years without cracking (due to longer autoclave run times for the 690 MA specimens). The assumption, based on SG operating experience, is that even if the onset of cracking were to occur at about 20 years, the Seabrook SGs might be expected to operate for at least another five years before replacement would be required. With the advanced SG design and more corrosion-resistant tube material, the useful life might be extended even further. However, some vulnerabilities in the Seabrook Unit 2 SGs may need to be dealt with. For example, eddy current indications have been observed at drilled support plate locations in a Palo Verde SG. The extent of the problem is unknown. Sleeving seems to offer a method to mitigate tube degradation at the baffle plate, if necessary.

Based on data found in the review, parallel extrapolations for secondary-side corrosion phenomena did not seem justified, under the scope of 
this investigation. Therefore, judgements regarding longer-term secondaryside behavior of the SG materials are based on extensive accelerated autoclave data showing no cracking for either the Alloy 600 TT or Alloy 690 TT materials. However, Appendix A, Table A2 suggests that extending the life of the Seabrook Unit 2 SGs would depend on the satisfactory control of chlorides and sulfates.

The combination of substantial, successful Mode1 F SG reactor service and evidence of improved corrosion resistance of thermally-treated Alloy 600, provides a positive basis for optimism that the Seabrook units can be expected to operate with adequate integrity for 20 to 25 years, with caveats indicated in Section 6.1.

\subsection{INDUSTRY COMMENTS REGARDING SG LONGEVITY}

It seems significant to note that plant spokesmen have sufficient confidence in the understanding of prior SG problems and the emerging positive service experience to go on record to the effect that they expect their SGs to serve the plant through its end of life. Examples of statements affirming this confidence in the performance of Model F SGs with Inconel 600 TT tubes appear in the following references:

- Surry-1 and -2, Nucleonics Week, July 27, 1989

- D. C. Cook, Nucleonics Week, July 27, 1989

- Callaway, Nucleonics Week, August 3, 1989

For example, the Callaway SG units began operation in 1984, so the utility spokesman is presumably projecting satisfactory operation over the 40-year period of the current license.

Confidence in SGs tubed with Alloy $690 \mathrm{TT}$ also is evident from the fact that three reactors are on line with tubes of that material and others are on order. However, proponents of Alloy 800 can also be found, and some investigators feel that "the jury is still out" on Alloy 690.

In a special report, problems with the Inconels and the status of their solutions (Nucleonics Week et a1. 1990) were addressed. Corrosion expert Phillipe Berge, of Electricité de France (EdF), was quoted as saying

\section{3}


"Personally, I am very confident in this material. Not that it will never leak. You can have loose parts, for example. But since 1981, we have thought it's the best optimization, and tests in those nine years have only confirmed that hypothesis." Berge is further quoted: "We can say that the problem of cracking [of Alloy 690] in primary water can be ruled out.... We have worked with this material more than any other material...There's a fantastic sum of data."

In France, Inconel 690 has been subjected to a test rig, simulating years of operation in an environment similar to a PWR primary circuit. Framatome spokesman Georges Slama said "I know of no material which has been so thoroughily tested. All of its characteristics are equal or superior to anything else on the market. Even in a sulfurous environment, where Inconel 690 will crack, you need more sulfur than for the other alloys, especially Inconel 600 , which is very sensitive."

Again quoting from Nucleonics Week et a1. (1990): "U.S. experts say they expect most if not all utilities to select Inconel 690 over Inconel 600 when replacing steam generators... But they are more cautious and hesitant to rule out potential problems that could be revealed after the new material is subjected to years of operating experience." "There's nothing to say the new Inconel 690 won't have its own particular characteristics," said Ted Marston of the Electric Power Research Institute.

One metallurgist for a U.S. vendor said his personal preference would be to stick with Inconel 600 , rather than switching to Inconel 690 with less service experience. 


\subsection{BEFERENCES}

Amar, A. S., and V. N. Shah. 1991. "Remedies for PWR Recirculating Steam Generator Tube Aging." CONF-890855-27, SMIRT-10, prepared by EG\&G Idaho, Inc., Idaho Falls, Idaho.

Aspden, R. G., T. F. Grand, and D. L. Harrod. 1989. "Corrosion Performance of Alloy 690." Presented at the Alloy 690 Workshop, New Orleans, Louisiana, Apri1 12-14, 1989.

Crawford, D. C., and G. S. Was. 1991. "Effect of Grain Boundary Misorientation on Intergranular Cracking of $\mathrm{Ni}-16 \mathrm{Cr}-9 \mathrm{Fe}$ in $360^{\circ} \mathrm{C}$ Argon and High Purity Water." In Fifth International Symposium on Environmental Degradation of Materials in Nuclear Power System-Water Reactors, Monterey, California.

Cullen, W. H., M. J. Partridge, J. A. Gorman, and J. P. Paine. 1991. "IGA/IGSCC of Alloy 600 in Acidic Sulfate and Chloride Solutions." Eifth International Symposium on Environmental Degradation of Materials in Nuclear Power System-Water Reactors, Monterey, California.

Donati, J. R., et a1. 1987. "Stress Corrosion Cracking Behavior of NickeiBase Alloys with 19\% Chromium in High Temperature Water." Third International Symposium on Environmental Degradation of Materials in Nuclear Power Systems - Water Reactors, Traverse City, August 30 to September 3, 1987, pp. 697-702.

Dow, B. L. 1991. Steam Generator Progress Report, Revision 7. Prepared by Energy Management Services, Inc., for the Electric Power Research Institute, Palo Alto, California, under Research Project S405-3.

Esposito, J. N., G. Economy, W. A. Byers, J. B. Esposito, F. W. Pement, R. J. Jacko, and C. A. Bergmann. 1991. "Zinc Addition for Enhanced Corrosion Resistance." Fifth International Symposium on Environmental Degradation of Materials in Nuclear Power System-Water Reactors, Monterey, California.

Gimond, C., P. Saint-Paul, J. Blanchet, and A. Klein. 1985. "Choix de L'Alliage 690 Pour Les tubes de Generateur de Vapeur." International Symposium, Contribution of Materials Investigations to the Resolution of Problems Encountered in PWR PIants, Fontevraud, France, p. 270.

Gold, R. E., D. L. Harrod, R. G. Aspden, and A. J. Baum. 1990. "Alloy 690 for Steam Generator Tubing Applications." EPRI NP-6997-SD, Electric Power Institute, Palo Alto, California.

Gras, J. M. 1991. "Stress Corrosion Cracking of Steam Generator Tubing Materials - Review and Assessment." Parkins Symposium on Fundamental Aspects of Stress Corrosion Cracking, Ed. S. M. Bruemmer, TMS Fall Meeting, TMS Warrendale, Pennsylvania. 
McIlree, A. R., T. Olberg, and J. Nestell. 1985. "Primary Side Stress Corrosion Cracking." Steam Generator Reference Book, EPRI-SGOD, Ch. 7, p. 14 .

Miglin, B. P., J. M. Sarver, D. W. Koch, K. Aokt, and H. Takamatsu. 1991. "Accelerated IGA/SCC testing of Alloy 600 in Contaminated PWR linvironments." Eifth International Symposium on Environmental Degradation of Materials in Nuclear Power System-Water Reactors, Monterey, California.

Miglin, B. P., and G. J. Theus. 1988, Stress Corrosion Cracking of Alloys 600 and 690 in A11-Volatile-Water at Elevated Temperatures. EPRI NP-5761, Electric Power Research Institute, Palo Alto, California.

Norring, K., K. Stiller, and J. Nilsson. 1991. "Grain Boundary Microstructure, Chemistry, and IGSCC in Alloy 600 and Alloy 690." Fifth International Symposium on Environmental Degradation of Materials in Nuclear Power System-Water Reactors, Monterey, California.

Nucleonics Week, et al. January 1990. "Outlook on Materials." Published by Nucleonics Week, Inside NRC, and Nuclearfuel, New York.

Sakai, T., T. Senjuh, K. Aoki, T. Shigemitsu, and Y. Kishi. 1991. "LeadInduced Stress Corrosion Cracking of Alloy 600 and 690." Fifth International Symposium on Environmental Degradation of Materials in Nuclear Power System-Water Reactors, Monterey, California.

Santarini, G., J. Blanchet, Y. Rouilion, J. C. VanDuysen, G. S1ama, and C. Gimond. 1989. "Alloy 690: Recent Corrosion Results.". Presented at the Alloy 690 Workshop, New Orleans, Loutsiana, April 12-14, 1989.

Smith, K., A. Klein, P. Saint-Paul, and J. Blanchet. 1985. "Inconel 690 - A Material with Improved Corrosion Resistance for PWR Steam Generator Tubes." Proceeding of the Second International Symposium on Environmental Degradation in Nuclear Power Systems - Water Reactors, Monterey, Cal ifornia, p. 319. American Nuclear Society, La Grange Park, I11inois.

Yonezawa, T., K. Onimura, N. Sasaguri, T. Kusakabe, H. Nagano, K. Yamanaka, T. Minami, and M. Inoue. 1985. "Effect of Heat Treatment on Corrosion Resistance of Alloy 690." International Symposium, Contribution of Materials Investigations to the Resolution of Problems Encountered in PWR Plants, Fontevraud, France, p. 287. 


\section{APPENDIX A}

IABLEA1. Comparison of Inconel $600 \mathrm{TT}$ and Inconel $690 \mathrm{TT}$ Properties

TABLE A2. Comparison of Corrosion Resistance for Inconels 600 and 690 in Several Environments Related to PWR Primary and Secondary Environments

TABLE A3. Trojan SG Characteristics and Status

IABLE A4. Seabrook SG Characteristics 
IABLEA A1. Comparison of Inconel 600 TT and Inconel 690 TT Properties

\section{Composition}

Alloy 600: $76 \% \mathrm{Ni}, 16 \% \mathrm{Cr}$, and $8 \% \mathrm{Fe}$.

Alloy 690 (nominal): $60 \% \mathrm{Ni}, 30 \% \mathrm{Cr}$, and $10 \% \mathrm{Fe} ; \mathrm{C}$ is 0.015 to $0.025 \%$.

\begin{tabular}{|c|c|c|c|c|c|c|c|c|c|}
\hline \multicolumn{10}{|c|}{$\begin{array}{c}\text { Chemical Composition of Alloys } 600 \text { and } 690 \text { Products Used for Caustio Stress } \\
\text { Corrosion Tests on Fracture Hechanics-Type Specimens (Nucleonics Heak. et al. 1990) } \\
\text { Chemical Composition. wtx }\end{array}$} \\
\hline Material & Product & Carbon & Sulfur & Phosphorus & stlicon & Manganese & Nickel & Chrominiun & Iron \\
\hline Alloy 600 & $\begin{array}{l}\text { plate, 20- } \\
\mathrm{mm} \text { thiok }\end{array}$ & 0.072 & 0.006 & 0.011 & 0.27 & 0.34 & 73.5 & 16.0 & 8.6 \\
\hline Alloy 690 & $\begin{array}{l}\text { bar, } 100 \\
\mathrm{~mm}\end{array}$ & 0.015 & 0.002 & 0.012 & 0.09 & 0.15 & 61.5 & 27.1 & 10.6 \\
\hline
\end{tabular}

II. Thermal Treatment

Applied to enhance corrosion resistance relative to MA condition:

Alloy 600 : $700^{\circ} \mathrm{C}$; minimum holding time is 10 to 15 hours

Alloy 690: 704 to $732^{\circ} \mathrm{C}\left(1300 \text { to } 1350^{\circ} \mathrm{F}\right)^{(\mathrm{a})}$; minimum holding time is 5 to 10 hours. (a)

III. Corrosion Characteristics

See Table A2.

IV. Wear Characteristics

Similar for Alloys 600 and 690.

V. Heat Transfer Characteristics

The thermal conductivity of Alloy 690 is estimated to be $2 \%$ to $4 \%$ lower than the Alloy 600 value in one case; laboratory data indicate an Alloy 690 thermal conductivity $8 \%$ to $9 \%$ below the Alloy 600 value (Nucleonics Week et a1. 1990).

(a) Includes the range of specifications by several organizations. 


\section{Mechanical Propert,jes}

\begin{tabular}{|l|c|c|c|}
\hline & YS, ksi & UTS, ksi & Elong., \% \\
\hline Alloy 600, Spec. SB-163 & $35 \mathrm{~min}$ & $80 \mathrm{~min}$ & 30 \\
\hline Alloy 690 , (a) Spec. SB 163 & $35 \mathrm{~min}$ & $85 \mathrm{~min}$ & 30 \\
\hline
\end{tabular}

(a) Laboratory testing has indicated that to reduce the potential for cracking, the yield stress for Alloy 690 TT should not exceed 56,000 psi (Ainarand Shah 1991).

\begin{tabular}{|c|c|c|c|c|c|c|c|c|}
\hline \multicolumn{9}{|c|}{$\begin{array}{l}\text { Tensile Properties of Alloys } 600 \text { and } 690 \text { Products Used for Caustic Stress } \\
\text { Corrosion Tests on Fracture Hechanios-Type Specimens (Nucleonios Week, et al. 1990) }\end{array}$} \\
\hline & & \multicolumn{3}{|c|}{ Room Temperature } & \multicolumn{3}{|c|}{$343^{\circ} \mathrm{C}$} & \\
\hline Material & $\begin{array}{c}\text { Heat } \\
\text { Treatment (a) }\end{array}$ & $\begin{array}{c}\text { Yield } \\
\text { Strength. } \\
\text { psi }\end{array}$ & $\begin{array}{c}\text { Uitimate } \\
\text { Strength. } \\
\text { psi }\end{array}$ & $\begin{array}{c}\text { Elong. . } \\
x\end{array}$ & $\begin{array}{c}\text { Yield } \\
\text { Strength. } \\
\text { poi } \\
\end{array}$ & $\begin{array}{c}\text { Ultimate } \\
\text { Strength. } \\
\text { psi }\end{array}$ & $\begin{array}{c}\text { Elong., } \\
x\end{array}$ & $\begin{array}{l}\text { Grain } \\
\text { Size, } \\
\text { ASTM } \\
\end{array}$ \\
\hline Alloy 600 & $\begin{array}{l}\text { MA } 950 \text { to } 980^{\circ} \mathrm{C} \\
\text { MA+HT } 16 \mathrm{~h} \text { at } 700^{\circ} \mathrm{C} \\
\text { SA } 1150^{\circ} \mathrm{C} \text { WQ } \\
\text { SA+HT } 16 \mathrm{~h} \text { at } 700^{\circ} \mathrm{C}\end{array}$ & $\begin{array}{l}52,200 \\
50,700 \\
32,600 \\
44,500 \\
\end{array}$ & $\begin{array}{l}110,000 \\
107,250 \\
91,300 \\
103,300 \\
\end{array}$ & $\begin{array}{l}36 \\
37 \\
56 \\
36 \\
\end{array}$ & $\begin{array}{l}42,000 \\
43,500 \\
27,500 \\
38,100 \\
\end{array}$ & $\begin{array}{l}98,600 \\
100,000 \\
88,400 \\
95,700 \\
\end{array}$ & $\begin{array}{l}35 \\
35 \\
64 \\
39 \\
\end{array}$ & $\begin{array}{l}8 \text { to } 9 \\
\text { id. } \\
2 \text { to } 6 \text { (het- } \\
\text { erogenous) }\end{array}$ \\
\hline Al10y 690 & $\begin{array}{l}\text { MA } 1035^{\circ} \mathrm{C} \\
\text { MA+HT } 16 \text { h at } 700^{\circ} \mathrm{C}\end{array}$ & $\begin{array}{r}34,800 \\
35,100 \\
\end{array}$ & $\begin{array}{l}91,300 \\
90,400 \\
\end{array}$ & $\begin{array}{l}55 \\
54 \\
\end{array}$ & $\begin{array}{c}26.100 \\
-.\end{array}$ & $\begin{array}{c}76,800 \\
\ldots \\
\end{array}$ & $\begin{array}{l}54 \\
-- \\
\end{array}$ & $\begin{array}{l}5 \text { to } 7 \\
\text { id. }\end{array}$ \\
\hline
\end{tabular}

(a). $\quad M A=m+11$ annealed; $H T=$ heat treated; $S A=$ solution annealed; and WQ = water quenched.

(b) Laboratory testing has indloated that to reduoe the potentlal for oracking, the yleld stress for Alloy 690 TT should not exceed 36,000 psi (Amarand Shah 1991). 
IABLE A2. Comparison of Corrosion Resistance for Alloys 600 and 690 in Several Environments Related to FiWR Primary and Secondary Environments

\begin{tabular}{|c|c|c|c|c|c|c|}
\hline & $\begin{array}{l}\text { Alloy } \\
600 \mathrm{MA} \\
\end{array}$ & $\begin{array}{l}\text { Alloy } \\
600 \text { SEN } \\
\end{array}$ & $\begin{array}{l}\text { Alloy } \\
600 \mathrm{TT} \\
\end{array}$ & $\begin{array}{l}\text { Alloy } \\
690 \mathrm{MA} \\
\end{array}$ & $\begin{array}{l}\text { Alloy } \\
690 \mathrm{TT} \\
\end{array}$ & $\begin{array}{l}\text { Alloy } \\
800 \mathrm{MA} \\
\end{array}$ \\
\hline \multicolumn{7}{|c|}{ STRESS CORROSION CRACKING: } \\
\hline Acid chloride & 1 & (2) & 1 & 1 & 1 & $(3-4)$ \\
\hline Caustic below $6 \%$ & $4-5$ & $3-4$ & 2 & (1) & 1 & 2 \\
\hline Caustic 10 to $15 \%$ & 4 & $(2-3)$ & 2 & 3 & 2 & 4 \\
\hline $\begin{array}{l}\text { Pure primary and } \\
\text { AVT water with } \mathrm{H}_{2}\end{array}$ & 4 & $(2-3)$ & $2-3$ & 1 & 1 & (1) \\
\hline Alkal ine sulfates & 1 & 1 & 1 & (1) & (1) & (1) \\
\hline Acid sulfates & 3 & $2-4$ & 1 & 1 & (1) & $\underline{U}$ \\
\hline $\begin{array}{l}\text { Sulfates p1us } \\
\text { chloride }\end{array}$ & 3 & 3 & 3 & 1 & (1) & 1 \\
\hline Sulfur & $(2-3)$ & (5) & 1 & 1 & 1 & U \\
\hline Lead & 4 & 4 & $\underline{U}$ & (1) & (1) & 1 \\
\hline $\begin{array}{l}\text { INTERGRANULAR } \\
\text { CORROSION }\end{array}$ & $(3-4)$ & $(2-3)$ & $(2-3)$ & $(1-2)$ & $(1-2)$ & $(4-5)$ \\
\hline $\begin{array}{l}\text { PITTING IN } \\
\text { CHLORIDES } \\
\end{array}$ & (3) & (3) & (3) & 2 & 2 & (3) \\
\hline \multicolumn{7}{|l|}{ WASTAGE: } \\
\hline Phosphates & (3) & U & U & (3) & U & (3) \\
\hline Sulfates & (3) & (3) & (3) & (1) & $u$ & (1) \\
\hline
\end{tabular}

Rankings: 1 = Best, 5 = Worst, ()$=$ Estimated, $U=$ Unknown.

Treatments: $M A=M i l 1$ Annealed, $T T=$ Thermally Treated, $S E N=$ Sensitized.

From EPRI Research Project S408-6, "Background Report - A1loy 690 for Steam Generator Tubing Applications," February 1990. 
IABLEA3. Trojan SQ Characteristics and Status

I. Characteristics

SG type: Series 51

Fabricated: 1971

Tube materials: Inconel $600 \mathrm{MA}$

Tube sheet/support plate: carbon steel

Tube sheet crevice type: tubes roll expanded and explosively expanded

Support plate crevice: drilled

Note - The Trojan SGs were initially subject to copper from heat

exchangers and condensers; by 1987, all copper alloy heat exchangers had been replaced.

II. Operating Conditions

Trojan reactor operating conditions:

- Primary system temperatures: inlet is $325^{\circ} \mathrm{C}\left(617^{\circ} \mathrm{F}\right)$; outlet is $289^{\circ} \mathrm{C}\left(552^{\circ} \mathrm{F}\right)$

- Primary system pressure: 2235 psig

- Secondary system temperature (nominal): $278^{\circ} \mathrm{C}\left(533^{\circ} \mathrm{F}\right)$

- Secondary system pressure: 908 psig

Primary system water chemistry:

- Hydrogen: $15 \mathrm{cc} / \mathrm{kg} ; 25$ to $35 \mathrm{cc} / \mathrm{kg}$

- Lithium: 0.2 to $0.5 \mathrm{ppm} \mathrm{Li} ; 6-77$ to $3-78$

- Boron: 0 to $2000 \mathrm{ppm} \mathrm{B}$ as boric acid

- Silica: $1.5 \mathrm{ppm}$ (initial) decreasing

Water chemistry: all volatile treatment (AVT) from start of commercial operation.

Note - Electric Power Research Institute (EPRI) water chemistry guidelines were instituted in 1988. 


\section{1991 Status}

Degradation mechanisms:

- U-Bend Cracking (Primary Side) - PNL examined cracked Trojan $U$-bend specimens under a contract with EPRI (Reference 1); all first row tubes plugged.

- Pitting - Discovered in 1982 on tube outer diameter surfaces, belleved to be caused by copper.

- Denting - Not a major problem due to AVT-only water chemistry.

- Intergranular Attack (IGA)

- OD SCC at tube support plates.

Tube Plugging - In 1991,700 tubes $(17.6 \%$ ) are plugged (estimated that $24 \%$ of tubes have some problem). 


\section{IABLE A4. Seabrook SG Characteristics}

\section{Characteristics}

SG type: Model F.

Fabricated: 1981 in the Westinghouse Tampa facility.

Tube materials: Alloy 600 TT.

Tube sheet/support plate: 405 stainless steel.

Tube sheet crevice type: hydraulic expansion.

Support plate crevice: quatrefoll broaches (thought to have flat lands).

J-tube material: carbon steel.

Feed ring material: carbon steel.

Flow distribution baffle crevices: drilled.

Access ports: six, 6-inch ports for sludge lancing and inspection.

Design Data (from the FSAR)

Design pressure, reactor coolant side: $2485 \mathrm{psig}$.

Design pressure, steam side: 1185 psig.

Design pressure, primary to secondary: 1600 psig.

Design temperature, reactor coolant side: $650^{\circ} \mathrm{F}$.

Design temperature, steam side: $600^{\circ} \mathrm{F}$.

Design temperature, primary to secondary: $650^{\circ} \mathrm{F}$.

Total heat transfer surface area: $55,000 \mathrm{ft}^{2}$.

Maximum moisture carry-over: 0.25 wt\%.

Overall height: $67 \mathrm{ft}, 8 \mathrm{in}$.

Number of $U$ tubes: 5626.

$U$ tube nominal diameter: $0.688 \mathrm{in}$.

Tube wall nominal thickness: $0.040 \mathrm{in}$.

Number of manways: 4 . 
Inside diameter of manways: 16 in.

Number of handholes: 6 .

Design fouling factor: $0.00005 \mathrm{ft}^{2}-\mathrm{hr}-{ }^{\circ} \mathrm{F} / \mathrm{Btu}$.

Steam flow: $3.78 \times 10^{6} \mathrm{lbs} / \mathrm{hr}$. 


\section{DISTRIBUTION}

No. of

Copies

\section{OFFSITE}

2 DOE/Office of Scientific and Technical Information

\section{T. Foley}

Battelle - Portland Operations

500 N.E. Multnomah Avenue

Suite 650

Portland, OR 97232

10

J. Irish

Bonneville Power Administration

P.0. Box 968, MD 399

Richland, WA 99352

J.P.N. Paine

Electric Power Research Institute P.0. Box 10412

Palo Alto, CA 94303

A. R. McIlree

Electric Power Research Institute P.0. Box 10412

Palo Alto, CA 94303

2 J. Carter

Portland General Electric Company Trojan Nuclear Plant

71760 Columbia River Highway

Rainier, OR 97048

J. Frewing

Port land General Electric Company 121 S.W. Salmon Street

Portland, OR 97204
No. of

Copies

ONSITE

\section{DOE Richland Field office}

J. Shadel

U.S. Department of Energy

Richland Field office

Research and Development Division

P.0. Box 550

Richland, WA 99352

28 Pacific Northwest Laboratory

S. H. Bush, MSIN K2-05

M. E. Cunningham, MSIN P8-10

J. L. Ethridge, MSIN P8-10

M. D. Freshley, MSIN P8-10

E. R. Gilbert, MSIN P8-34

R. L. Grue1, MSIN K6-46

A. B. Johnson, Jr., MSIN P8-10

R. J. Kurtz, MSIN K2-3I (5)

R. D. Orton

G. L. Tingey, MSIN P8-10

Publishing Coordination

Technical Report Files (5) 


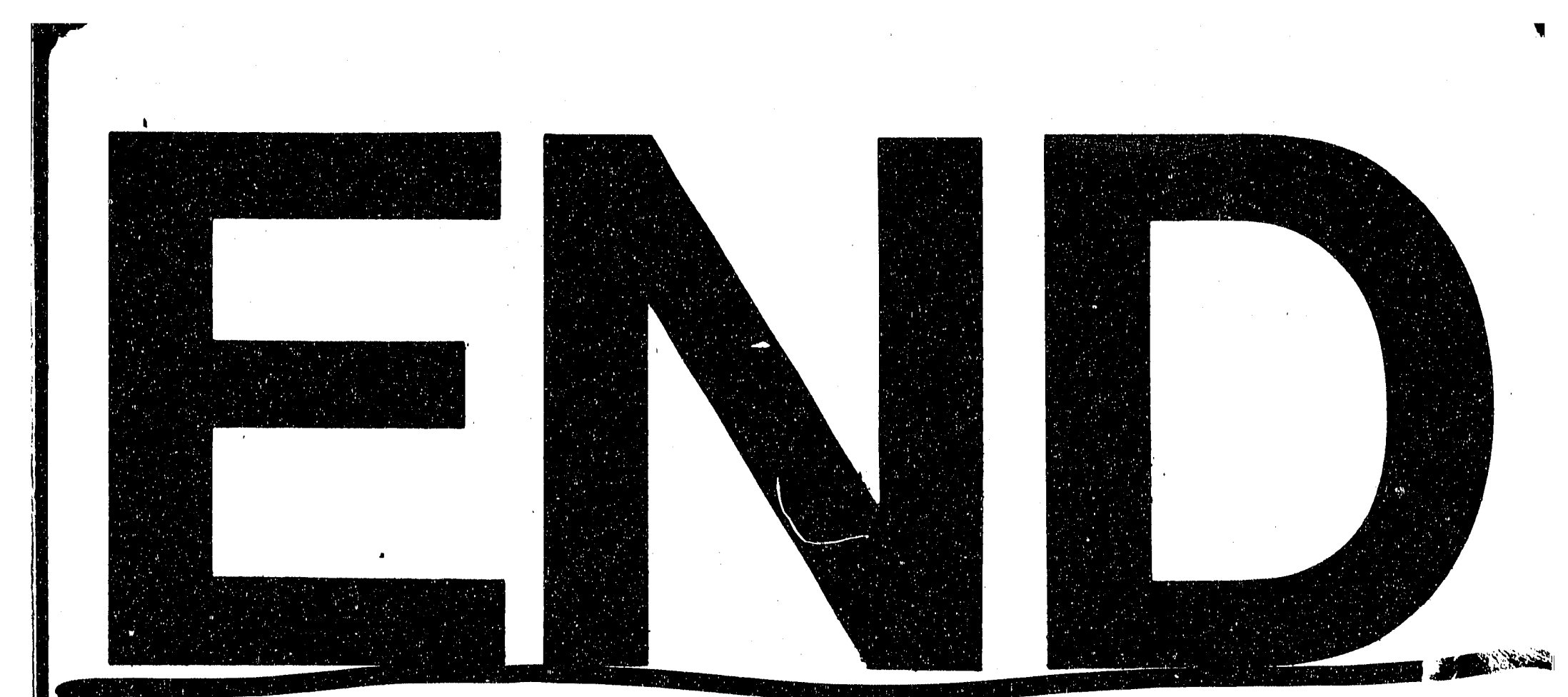




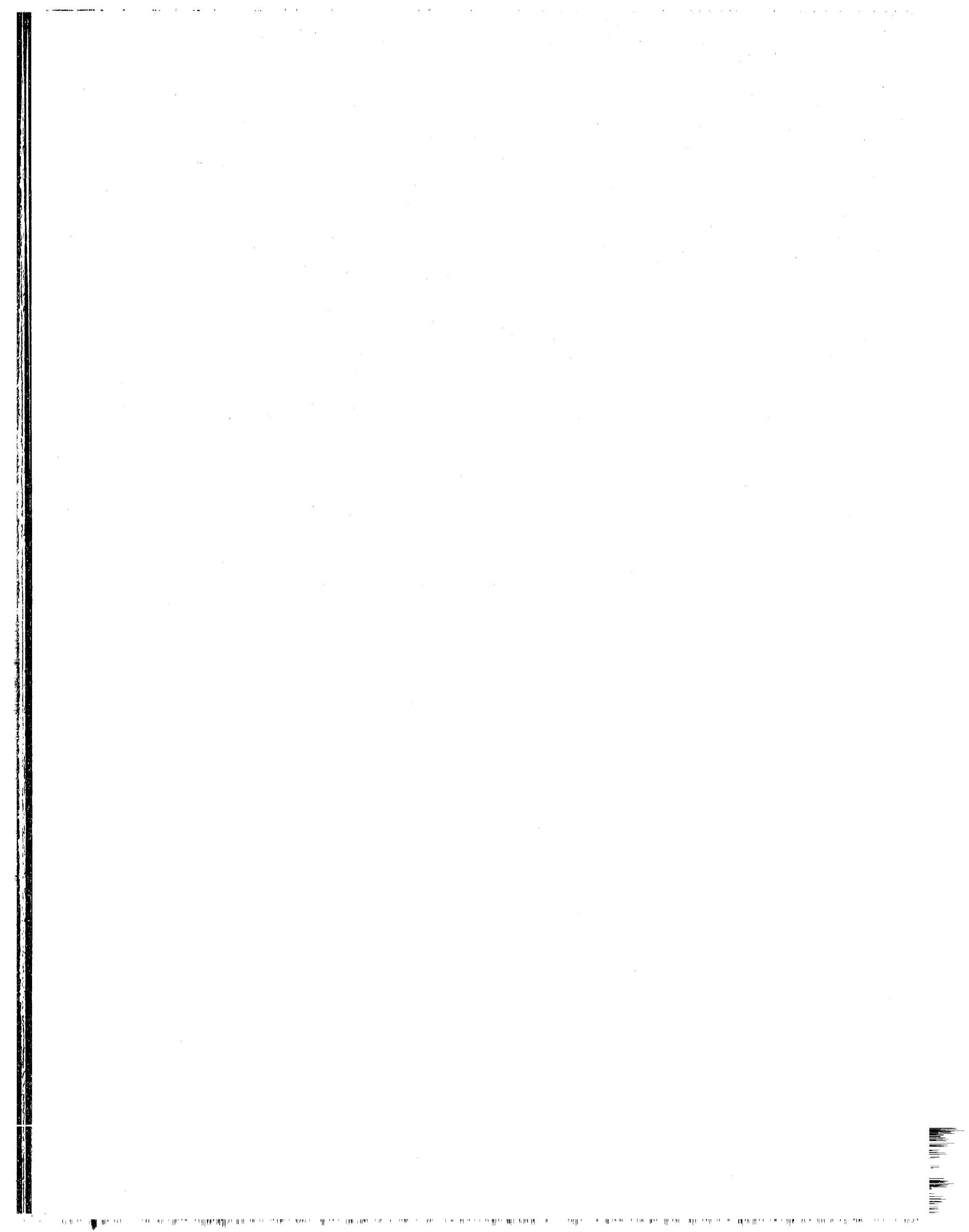

